\title{
SURVEY OF CHESS “PROFILE” OF SECONDARY SCHOOL PUPILS
}

\author{
Leyla Dimitrova \\ National Sports Academy "Vassil Levski”, Sofia, Bulgaria
}

\begin{abstract}
The main purpose of the survey was to obtain basic information about school students' attitude towards inschool and after-school chess activities. The second purpose of this study was to identify the key motivation factors for pupils' wish for chess tuition in school. The third objective was to estimate the importance of chess-playing families as a background for the introduction of chess to the school environment. Research sampled a group of 62 children aged between 11 and 14 (boys: 35; girls: 27) from 10 Bulgarian cities. The most important questions we focused on were: "Who are you playing with?"; "Does anybody from your family play chess?"; "Would you attend chess lessons in your school?"; "How often would you like to attend chess lessons in your school?" The first key theme that emerged from the data: the students' attitudes towards in-school and after-school chess activities were significantly positive. In the second instance it was instructive to view the influence of chess-playing families on pupils' motivation to learn chess in school. Both the classroom and family are bonding environment with mutual influence on each other.
\end{abstract}

Key words: chess in school, chess-playing families

\section{Introduction}

As teachers and parents battle with the distractions of electronic games, social media and attention deficit disorder among younger generations, the supporters of chess education argue that it is a great way for children to learn about fair competition, mental discipline, planning and perseverance. Clubs and federations focus on developing chess as a sport. But we believe that chess has more to offer mainly as a tool for educational benefits, such as concentration, critical thinking, abstract reasoning, problem solving, pattern recognition, strategic planning, creativity, analysis, synthesis, and evaluation, to name a few. A series of evaluation studies have been made on the effects of chess teaching on performance in the academic, cognitive and behavioral domains. Most studies (Redman Tim (2006); McDonald, P.S. $(2005,2006))$ concluded playing chess could raise IQ scores, strengthen problem solving skills, enhance memory and foster creative thinking. Chess is part of the curricula in nearly 30 countries. In Venezuela, Iceland, Russia, Armenia and other countries, chess is a subject in all public schools. From September, 1st, 2017 chess will be implemented in primary schools in Poland as a tool for learning mathematics. In countries where chess is offered widely in schools, students exhibit excellence in the ability to recognize complex patterns and consequently excel in math and science (Milat, 1997).

The acceptance of the Initiative of the EU Parliament in March 2012 to bring chess into the school system in EU-members was seen as an important milestone in Bulgaria. There school chess is considered as one of most important topics for Bulgarian chess federation.

The main purpose of the survey was to obtain basic information about school students' attitude towards in-school and after-school chess activities and to investigate their opinion on chess tuition in school. The second purpose of this study was to identify the key motivation factors for pupils' wish for chess tuition in school. The third objective was to estimate the importance of chess-playing families as a background for the introduction of chess to the school environment.

Our hypothesis: The survey of school students' opinion about in-school and after-school chess activities will show their attitude towards introduction of chess lessons to the secondary school curriculum.

\section{Methods}

For the analysis of the qualitative data we used chisquare test. The $\chi^{2}$ statistic is based on the difference between the expected and the observed number of cases and it permits to test our hypothesis. Research sampled a group of 62 children aged between 11 and 14 (boys: 35; girls: 27) from 10 Bulgarian cities. They were asked to complete a brief questionnaire. Majority of the questions concerned in- and after-school informal chess activities. Most questions included several answer suggestions. The most important items we focused on were: "Who are you playing with?"; "Does anybody from your family play chess?"; "Would you attend chess lessons in your school?"; "How often would you like to attend chess lessons in your school?" In-depth 
interviews and focus group discussion were also used.

\section{Results}

Who do you play with more often?

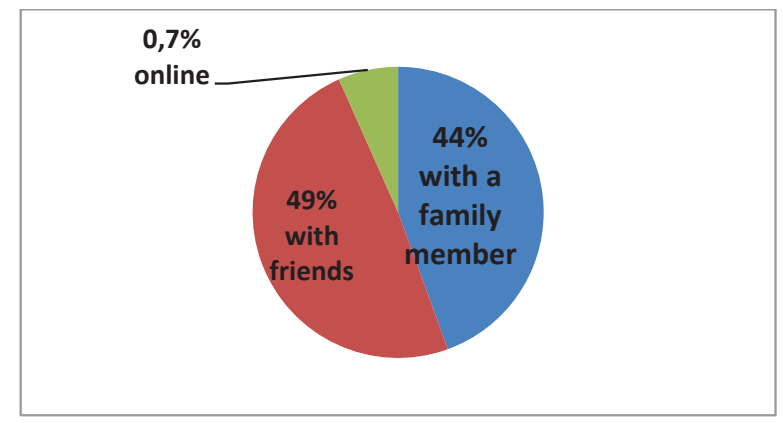

Fig.1 Distribution of answers of the question: Who do you play with more often?

$49 \%$ of students enjoy playing chess with friends while $44 \%$ usually play with a family member. Despite of great electronic chess game development only $7 \%$ of students play chess online. And none of them mentioned actual chess site. None of them attends a chess club or uses chess software either. Respondents indicated they easily find a partner to play with and most common opponents are friends and family members.

Does anybody from your family play chess?

More than a half of pupils stated that at least one family member plays chess. Most common this is father $-51,5 \%$ of answers, followed by grandfather $-24,2 \%$, brother $-15,2$, mother $-6,1 \%$ and sister - 3\%. Observations have shown that children learn to play chess more quickly if their teacher is older brother or sister or elder relative. Ideally, a parent or someone else at home knows the game and can play at least a basic game with the child.

For studying family impact on students' motivation we used the following table:

Table1. Impact of family factor

\begin{tabular}{|l|l|l|l|l|}
\hline \multicolumn{5}{|l|}{ family ${ }^{\star}$ can play chess Crosstabulation } \\
\hline Count & & \multicolumn{4}{l|}{} \\
\hline & & \multicolumn{4}{|l|}{ Can play chess } \\
\hline & & Y & N & Total \\
\hline Family member & can play & 27 & 6 & 33 \\
\hline & can't play & 12 & 17 & 29 \\
\hline & Total & 39 & 23 & 62 \\
\hline
\end{tabular}

Data was analyzed with software SPSS16

Table2. Results of $\chi 2$-analysis

\begin{tabular}{|l|l|l|l|l|l|}
\hline Chi-Square Tests & \multicolumn{7}{|l|}{} \\
\hline & Value & df & $\begin{array}{l}\text { Asymp. Sig. } \\
\text { (2-sided) }\end{array}$ & $\begin{array}{l}\text { Exact Sig. } \\
\text { (2-sided) }\end{array}$ & $\begin{array}{l}\text { Exact Sig. } \\
\text { (1-sided) }\end{array}$ \\
\hline Pearson Chi-Square & $10,817^{\mathrm{a}}$ & 1 &, 001 & & \\
\hline $\begin{array}{l}\text { Continuity Correc- } \\
\text { tion }\end{array}$ & 9,154 & 1 &, 002 & & \\
\hline Likelihood Ratio & 11,145 & 1 &, 001 & & \\
\hline Fisher's Exact Test & & & &, 001 &, 001 \\
\hline $\begin{array}{l}\text { Linear-by-Linear } \\
\text { Association }\end{array}$ & 10,643 & 1 &, 001 & & \\
\hline $\begin{array}{l}\text { N of Valid Cases } \\
6\end{array}$ & 62 & & & \\
\hline $\begin{array}{l}\text { a. } 0 \text { cells (,0\%) have expected count less than 5. The minimum ex- } \\
\text { pected count is 10,76. }\end{array}$ \\
$\begin{array}{l}\text { b. Computed only for a } \\
\text { 2x2 table }\end{array}$ \\
\hline
\end{tabular}

The role of the educator is very important in our new age of modern technologies that requires a different skill set. Parents see the need for students to develop healthy habits of mind and value the critical thinking and creative problem solving skills inherent in studying and playing chess. The development of intergenerational chess play between parent and child and grandparent and child generate a new period of quality time at home for adult-child relations.

Would you attend chess lessons in your school?

In school we can't avoid "classroom-style" of chess teaching, which conflicts with pupils' aspiration for more physical activities. Nevertheless a huge majority of respondents $-62,9 \%$ answers they would like to attend chess lessons in their school. A quarter wouldn't attend such lessons, while 11,3\% have no opinion.

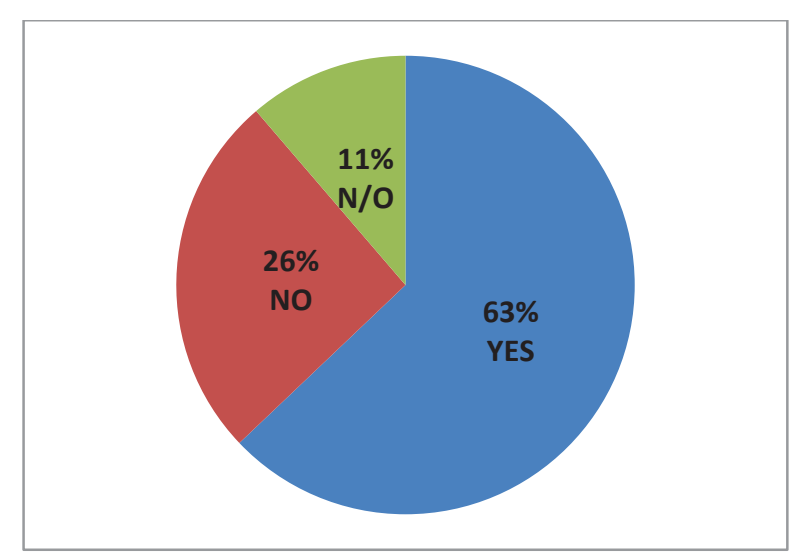

Fig.2 Would you attend chess lessons in your school?

How often would you like to attend chess lessons in your school? 
Overall 66 per cent of the children said they would like to try chess once a week. These results correspond with the idea that scholastic chess movement has to be focused on bringing the students educational benefits and not to be used mainly to attract junior club members. According to us chess being taught within normal class time for one hour a week by accredited chess coaches will be a good start. Many students are engaged in other activities. However, two hours per week are usually enough for a busy person to make sensible progress in chess if he follows a structured program of study and training.

About one fifth of pupils want to learn chess twice a week, while the most enthusiastic $11,3 \%$ would like to have chess lessons three times per week.

\section{Conclusions}

This paper is targeted to stimulate debate on chess in schools. It is not possible to draw general conclusions from the survey, but it discloses school students' attitude towards in-school and after-school chess activities.

The research showed that the children, living in the cities and those living in the smaller towns have the same attitude towards playing chess. A significant factor for children's attitude to chess is the presence of a family member who is good at playing the game.

Chess has become a part of modern education and is pro-family, pro-education and pro-social.

Reports from students noticed they have significant positive attitude to learning chess in school.

Incorporation of chess into the curriculum of schools must be promoted and encouraged.

\section{References}

Horgan, R. W., \& Morgan, D. (1990). Chess expertise in young children. Applied Cognitive Psychology, 4, 109128.

McDonald, P.S. $(2005,2006)$ The Benefits of Chess in Education, a collection of studies and papers on chess in education.

Milat, M. (1997). The role of chess in modern education. [Online]. Available: https://www.kidchess.com/milat_ roleofchess.htm

Redman Tim (2006). Chess and education: Selected essays from the Koltanowski conference. Dallas, TX: Chess Program at the University of Texas at Dallas. 